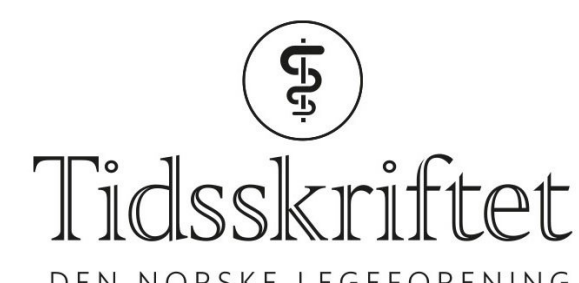

DEN NORSKE LEGEFORENING

\title{
Suturtråd i luftveiene
}

MEDISINEN I BILDER

\section{OLE H. MYRDAL}

E-post: omyrda@ous-hf.no

Lungeavdelingen

Oslo universitetssykehus, Rikshospitalet

Ole H. Myrdal er spesialist i indremedisin og i lungesykdommer.

Forfatteren har fylt ut ICMJE-skjemaet og oppgir ingen interessekonflikter.

\section{ARVE SUNDSET}

Lungeavdelingen

Oslo universitetssykehus, Rikshospitalet

Arve Sundset er spesialist i indremedisin og i lungesykdommer og er overlege.

Forfatteren har fylt ut ICMJE-skjemaet og oppgir ingen interessekonflikter.

\section{TROND MOGENS AALØKKEN}

\section{Radiologisk avdeling}

Oslo universitetssykehus, Rikshospitalet

Trond Mogens Aaløkken er spesialist i radiologi og er overlege.

Forfatteren har fylt ut ICMJE-skjemaet og oppgir ingen interessekonflikter.

\section{AUDHILD HJALMARSEN}

Lungemedisinsk avdeling

Universitetssykehuset Nord-Norge

og

Institutt for klinisk medisin

Norges arktiske universitet - Universitetet i Troms $\emptyset$

Audhild Hjalmarsen er spesialist i indremedisin og i lungesykdommer, overlege og førsteamanuensis.

Forfatteren har fylt ut ICMJE-skjemaet og oppgir ingen interessekonflikter.

På bildet, tatt ved bronkoskopi, ses suturmateriale og purulent slim som ligger endobronkialt, nær ostiet for det apikale underlappssegment på høyre side. 


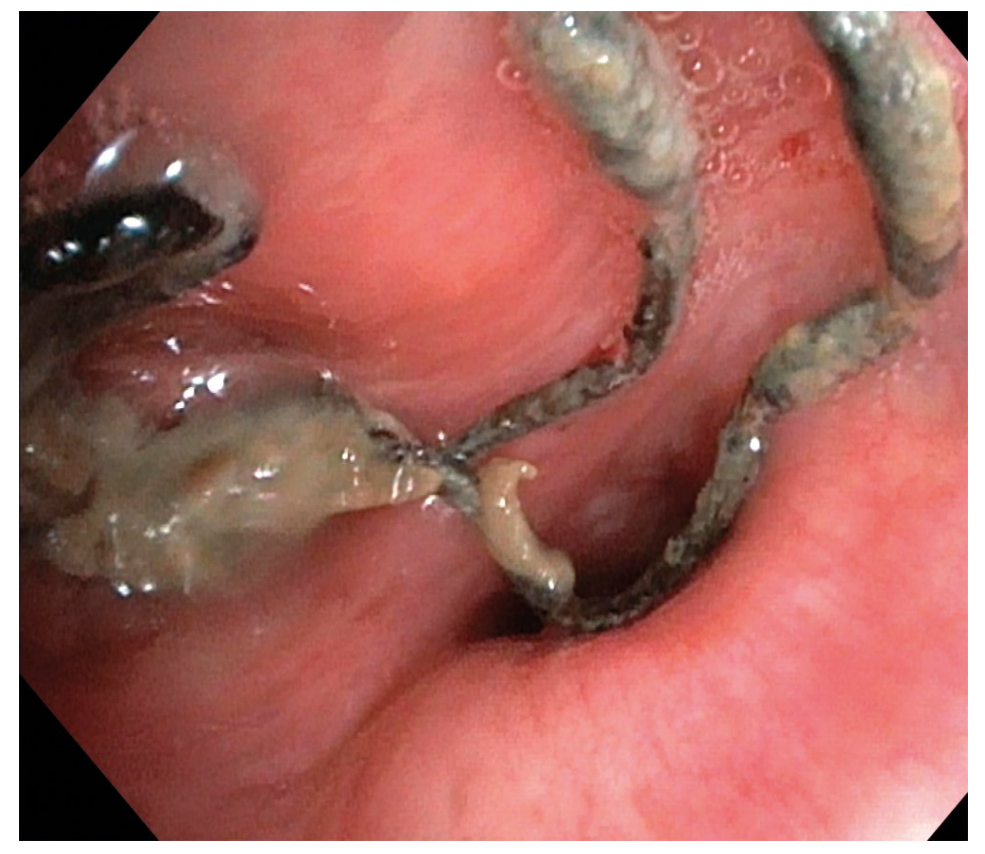

Pasienten er en kvinne i 5o-årene. Som barn ble hun operert med partiell høyresidig underlappsektomi. Man lot det apikale underlappssegmentet stå igjen, og det ble brukt ikke-resorberbar tråd. Etter operasjonen har hun hatt tilbakevendende nedre luftveisinfeksjoner, alt fra bronkitt til pneumoni. Forut for den aktuelle bronkoskopien ble det gjort CT thorax som avdekket abscessutvikling (CT-bilde). Ved utredning fant man ingen underliggende immunsvikt eller andre forklaringer på infeksjonstendensen. Hun røyker daglig, men har ingen obstruktiv lungesykdom. Suturmaterialet som ble avdekket ved bronkoskopi var i retrospekt synlig på CT thorax-bildet, men kunne muligens mistolkes som sekret i luftveiene.

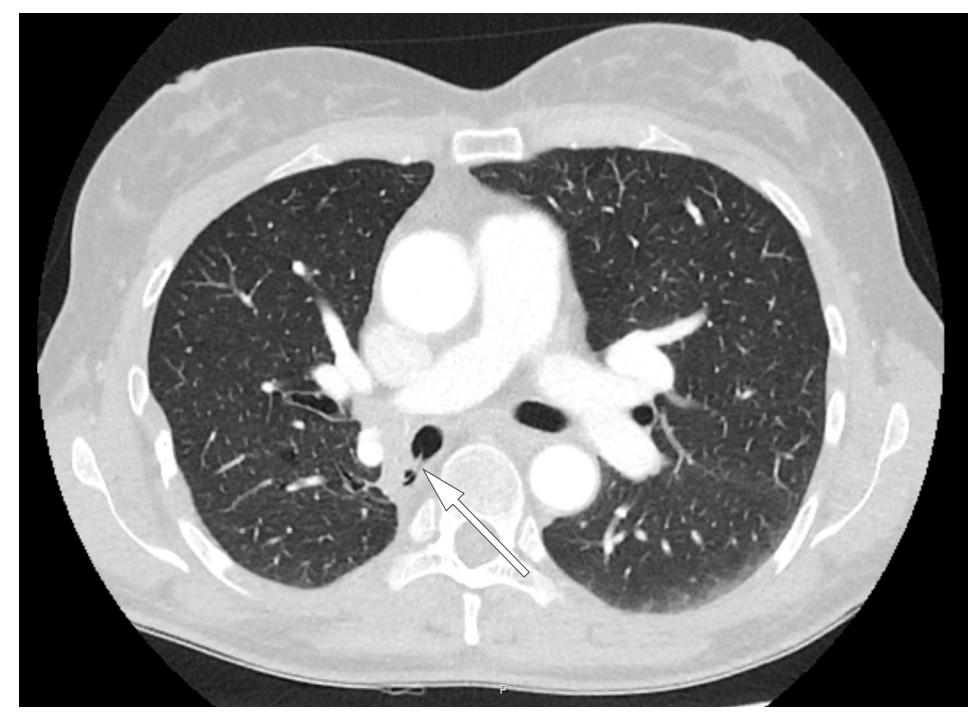

Suturmateriale er som et fremmedlegeme og fremmer dannelse av en biofilm og bakteriekolonisering. Dette er høyst sannsynlig årsaken til gjentatte pneumonier og utviklingen av lungeabscess (1). De synlige suturene lot seg fjerne med tang bronkoskopisk. Prosedyren ble gjort først etter at pasienten hadde gjennomført langvarig antibiotikabehandling. Selv om det hadde gått mer enn 40 år siden operasjonen fant sted, var ikke suturmaterialet brutt ned. I litteraturen har vi funnet bare få rapporter om fjerning av aspirert fremmedlegeme med tilsvarende tidsspenn fra aspirasjon til fjerning (2). I disse tilfellene har indikasjonen for utredningen vært tilbakevendende pneumonier, slik som hos vår pasient. Det vi kan lære av kasuistikken, er at hos pasienter med gjentatte nedre luftveisinfeksjoner av ukjent årsak bør man vurdere CT thorax og bronkoskopi. 
1. al-Majed SA, Ashour M, al-Mobeireek AF et al. Overlooked inhaled foreign bodies: late sequelae and the likelihood of recovery. Respir Med 1997; 91: 293-6. [PubMed][CrossRef]

2. Kogure Y, Oki M, Saka H. Endobronchial foreign body removed by rigid bronchoscopy after 39 years. Interact Cardiovasc Thorac Surg 2010; 11: 866-8. [PubMed][CrossRef]

Publisert: 8. august 2019. Tidsskr Nor Legeforen. DOI: 10.4045/tidsskr.19.0089

Mottatt 29.1.2019, første revisjon innsendt 22.4.2019, godkjent 3.5.2019.

(C) Tidsskrift for Den norske legeforening 2020. Lastet ned fra tidsskriftet.no 